\title{
Molecular Systematics of the Firefly Genus Luciola (Coleoptera: Lampyridae: Luciolinae) with the Description of a New Species from Singapore
}

\author{
Wan F. A. Jusoh ${ }^{1, *(\mathbb{D} \text {, Lesley Ballantyne }}{ }^{2}$, Su Hooi Chan ${ }^{3}$, Tuan Wah Wong ${ }^{4}$, Darren Yeo ${ }^{5}$, B. Nada ${ }^{6}$ (D) \\ and Kin Onn Chan $1, * \mathbb{D}$
}

check for

updates

Citation: Jusoh, W.F.A.; Ballantyne, L.; Chan, S.H.; Wong, T.W.; Yeo, D.;

Nada, B.; Chan, K.O. Molecular Systematics of the Firefly Genus Luciola (Coleoptera: Lampyridae: Luciolinae) with the Description of a New Species from Singapore. Animals 2021, 11, 687. https://doi.org/ 10.3390/ani11030687

Academic Editor: Félix Goyache

Received: 27 January 2021

Accepted: 26 February 2021

Published: 4 March 2021

Publisher's Note: MDPI stays neutral with regard to jurisdictional claims in published maps and institutional affiliations.

Copyright: (c) 2021 by the authors. Licensee MDPI, Basel, Switzerland. This article is an open access article distributed under the terms and conditions of the Creative Commons Attribution (CC BY) license (https:// creativecommons.org/licenses/by/ $4.0 /)$.
1 Lee Kong Chian Natural History Museum, National University of Singapore, Singapore 117377, Singapore

2 School of Agricultural and Wine Sciences, Charles Sturt University, Wagga Wagga 2678, Australia; lballantyne@csu.edu.au

3 Central Nature Reserve, National Parks Board, Singapore 573858, Singapore; chan_su_hooi@nparks.gov.sg

4 National Parks Board HQ (Raffles Building), Singapore Botanic Gardens, Singapore 259569, Singapore; tuanwah@gmail.com

5 Department of Biological Sciences, National University of Singapore, Singapore 117543, Singapore; dbsdy@nus.edu.sg

6 Forest Biodiversity Division, Forest Research Institute Malaysia, Kepong 52109, Malaysia; nada@frim.gov.my

* Correspondence: wfawan@gmail.com (W.F.A.J.); cko@nus.edu.sg (K.O.C.)

Simple Summary: Fireflies have a scattered distribution in Singapore but are not as uncommon as many would generally assume. A nationwide survey of fireflies in 2009 across Singapore documented 11 species, including "Luciola sp. 2", which is particularly noteworthy because the specimens were collected from a freshwater swamp forest in the central catchment area of Singapore and did not fit the descriptions of any known Luciola species. Ten years later, we revisited the same locality to collect new specimens and genetic material of Luciola sp. 2. Subsequently, the mitochondrial genome of that population was sequenced and specimens were subjected to rigorous morphological examinations. We then collated published mitogenomes and shorter mitochondrial markers from closely related taxa to infer a phylogeny for the subfamily Luciolinae. Our results reveal that Luciola sp. 2 is both genetically and morphologically distinct from other congeners and is thus described herein as a new species Luciola singapura sp. nov. This marks the first time since 1909 that a new species of luminous firefly has been discovered in Singapore, highlighting the need for continued biodiversity research, even in small, well-studied and highly developed countries such as Singapore that can still harbor undescribed biodiversity.

Abstract: The firefly genus Luciola sensu McDermott contains 282 species that are distributed across major parts of Asia, Europe, Africa, Australia, and the Pacific islands. Due to phenotypic similarities, species identification using external morphological characters can be unreliable for this group. Consequently, decades of piecemeal taxonomic treatments have resulted in numerous erroneous and contentious classifications. Furthermore, our understanding of the group's evolutionary history is limited due to the lack of a robust phylogenetic framework that has also impeded efforts to stabilize its taxonomy. Here, we constructed molecular phylogenies of Luciola and its allies based on combined mitogenomes and Cytochrome c oxidase subunit 1 (COX1) sequences including a newly sequenced mitogenome of an unidentified taxon from Singapore. Our results showed that this taxon represents a distinct and hitherto undescribed evolutionary lineage that forms a clade with L. filiformis from Japan and L. curtithorax from China. Additionally, the Singaporean lineage can be differentiated from other congeners through several external and internal diagnostic morphological characters, and is thus described herein as a new species. Our phylogeny also strongly supported the paraphyly of Luciola with regard to L. cruciata and L. owadai, which were inferred to be more closely related to the genus Aquatica as opposed to other members of Luciola sensu stricto. The genus Hotaria was inferred as a derived clade within Luciola (sister to L. italica), supporting its status as a subgenus of Luciola instead of a distinct genus. This is the first time since 1909 that a new species of luminous firefly has 
been discovered in Singapore, highlighting the need for continued biodiversity research, even in small, well-studied and highly developed countries, such as Singapore.

Keywords: Hotaria; Luciola cruciata; Luciola owadai; Nee Soon Swamp Forest; taxonomy; phylogenetics; conservation

\section{Introduction}

Firefly beetles (Coleoptera: Lampyridae) comprise over 2000 species globally. The subfamily Luciolinae-all of which are exclusively flashing fireflies-represents a diverse subfamily (>400 species) distributed across Europe, Africa, Asia, Australia, and the Pacific islands [1,2]. The bulk of lucioline species ( 303 species) occur in Southeast (SE) Asia and the Australopacific region, which encompasses the following geographic units: India, Sri Lanka, Bangladesh, China (including Hong Kong), Taiwan, Korea, Japan, Myanmar, Laos, Cambodia, Vietnam, Thailand, Malaysia, Singapore, Indonesia, Philippines, the Republic of Palau, the Federated States of Micronesia, Papua New Guinea, West Papua, Solomon Islands, New Caledonia, Vanuatu, Fiji, and Australia [3]. The continents of Africa and Europe have a combined total of at least 100 lucioline species [4].

In the 19th century, the taxonomy of Luciolinae relied heavily on external features such as colour pattern of the dorsal surface, male terminal abdomen, and prominence of the elytral carina as diagnostic characters [2,5]. However, for the genus Luciola Laporte, the most speciose genus in the subfamily Luciolinae $[4,6,7]$, species identification based on external morphological characters is problematic due to overlapping phenotypic similarities [2,8]. Decades of piecemeal taxonomic treatments coupled with the lack of a robust phylogenetic framework have resulted in the genus being a dumping ground for ambiguous taxa, leading to protracted taxonomic instability, contentious classifications, and unnatural taxonomic groupings [9-11].

In 1966, 282 species were listed under the genus Luciola by McDermott in the world catalogue of Lampyridae, to which 279 species were assigned to the subgenus Luciola, and one species, respectively, to the following subgenera: Hotaria Yuasa, Photuroluciola Pic, and Pygoluciola Wittmer [4]. After McDermott, a large number of SE Asian and Australopacific lucioline taxa (mostly within the subgenus Luciola) were subjected to numerous revisions, redefinitions, and rearrangements, leading to widespread taxonomic changes and instability [1-3,5,8,10,12-15].

In 2019, Ballantyne et al. [3] assigned 17 species to Luciola s. str.-a group defined by several morphological characteristics shared with the type species of Luciola, L. italica (L. [16]), primarily: 1. visible view of aedeagal lateral lobes (LL) beside the medium lobe (ML), with a clear separation of the aedeagal lateral lobe along the inner dorsal length; 2. presence of either curved or arched medium lobe terminating in a preapical ventral point; 3. presence of elongated, narrow, pointed lobes ("leaf like") arising from the inner ventral margins of the lateral lobes (some species, including L. italica) [8]. The remaining 40 species in the genus Luciola have yet to undergo thorough morphological assessments. Of these, Ballantyne et al. [3] highlighted seven species (including Luciola costata Pic) that could potentially be transferred to the genus Curtos without formalizing the move; the remaining 33 species (including two synonyms) were assigned to Luciola s. lato [3] which is a loose category that lacks a proper definition.

Two well-known and revered firefly species from Japan, Luciola cruciata Motschulsky and Luciola owadai Sâtô and Kimura do not fit the definition of Luciola and were provisionally considered as "taxonomic position unresolved" [3]. Their distinction from Luciola s. str. was further corroborated by molecular phylogenetic analyses [15]. Meanwhile, Photuroluciola and Pygoluciola were removed from the subgenus Luciola sensu McDermott and elevated to the genus rank [12,13,17-19], while Luciola parvula Kiesenwetter, the type species of the subgenus Hotaria sensu McDermott was transferred to Luciola s. str. [3,15]. Nonetheless, 
the taxonomic rank of Hotaria is still in question because after McDermott, Hotaria was still being recognized as a distinct genus in some studies, e.g., [20,21], while most studies recognized it as a subgenus of Luciola, e.g., [22]. Hotaria previously consisted of four species: Luciola parvula, L. unmunsana Doi, L. papariensis Doi, and L. tsushimana Nakane; the latter two were subsequently synonymised with L. unmunsana [23].

In Singapore, a small, highly urbanized, and bustling city-state in SE Asia, fireflies have a scattered distribution but are not as uncommon as many would generally assume. A nationwide survey of fireflies in 2009 at 14 sites across Singapore documented 11 species [24]. Included in that survey was an unidentified species, "Luciola sp. 2", which was particularly noteworthy because the specimens were collected from a freshwater swamp forest in the central catchment area of Singapore and did not fit the descriptions of any known Luciola species. Several years later, while examining the Lampyridae collection in the Zoological Reference Collection (ZRC) at the Lee Kong Chian Natural History Museum in Singapore, the first author discovered three additional dry specimens collected in 1989 and 1990 from the same locality that were morphologically similar to Luciola sp. 2. For this study, we revisited the same locality to collect new specimens and genetic material of Luciola sp. 2. Subsequently, the mitochondrial genome of that population was sequenced and specimens were subjected to rigorous morphological examinations. We then collated published mitogenomes from closely related taxa to infer a molecular phylogeny to serve as an evolutionary framework to aid taxonomic classification and species delineation. The mitogenomic dataset was also supplemented with shorter mitochondrial markers from additional taxa to fill-in taxonomic sampling gaps. Results from morphological examinations and phylogenetic analyses were used to determine if (1) Luciola sp. 2 represents a unique evolutionary lineage warranting specific recognition and (2) the morphological definition of Luciola s. str. is consistent within an evolutionary framework that is supported by robust molecular data.

After 30 years since its initial discovery, our results indicate that Luciola sp. 2 is a distinct evolutionary lineage that is both genetically and morphologically distinct from other congeners and is thus described herein as a new species, Luciola singapura sp. nov. This marks the first time since 1909 that a new species of luminous firefly has been discovered in Singapore [25], highlighting the need for continued biodiversity research, even in small, well-studied and highly developed countries such as Singapore that can still harbor undescribed biodiversity.

\section{Materials and Methods}

\subsection{Study Site and Field Sampling}

Singapore is the second smallest country in Asia $\left(\sim 728 \mathrm{~km}^{2}\right)$ and comprises four legally protected nature reserves covering approximately $4 \%$ of its total land area [23]. For this study, specimens were collected exclusively from the Nee Soon Swamp Forest (hereafter referred to as NSSF) which is part of the Central Catchment Nature Reserve (Figure 1). The NSSF is an important conservation site that is rich in biodiversity and is the only remaining patch of primary freshwater swamp forest in Singapore [26].

We conducted night surveys in NSSF between 7.30 p.m. and 10.30 p.m. on 9 October 2018, 11 October 2018, 11 January 2019, and 18 January 2019. These surveys specifically targeted specimens that matched the description of Luciola sp. 2 sensu [24]. In total, four specimens comprising three males and one female were collected, all of which were found during surveys conducted in January. We also examined specimens deposited in the Zoological Reference Collection (ZRC) at the Lee Kong Chian Natural History Museum, Singapore, including two specimens collected by Chan and colleagues in 2009. The ZRC is the sole depository of all specimens examined, including type material. 


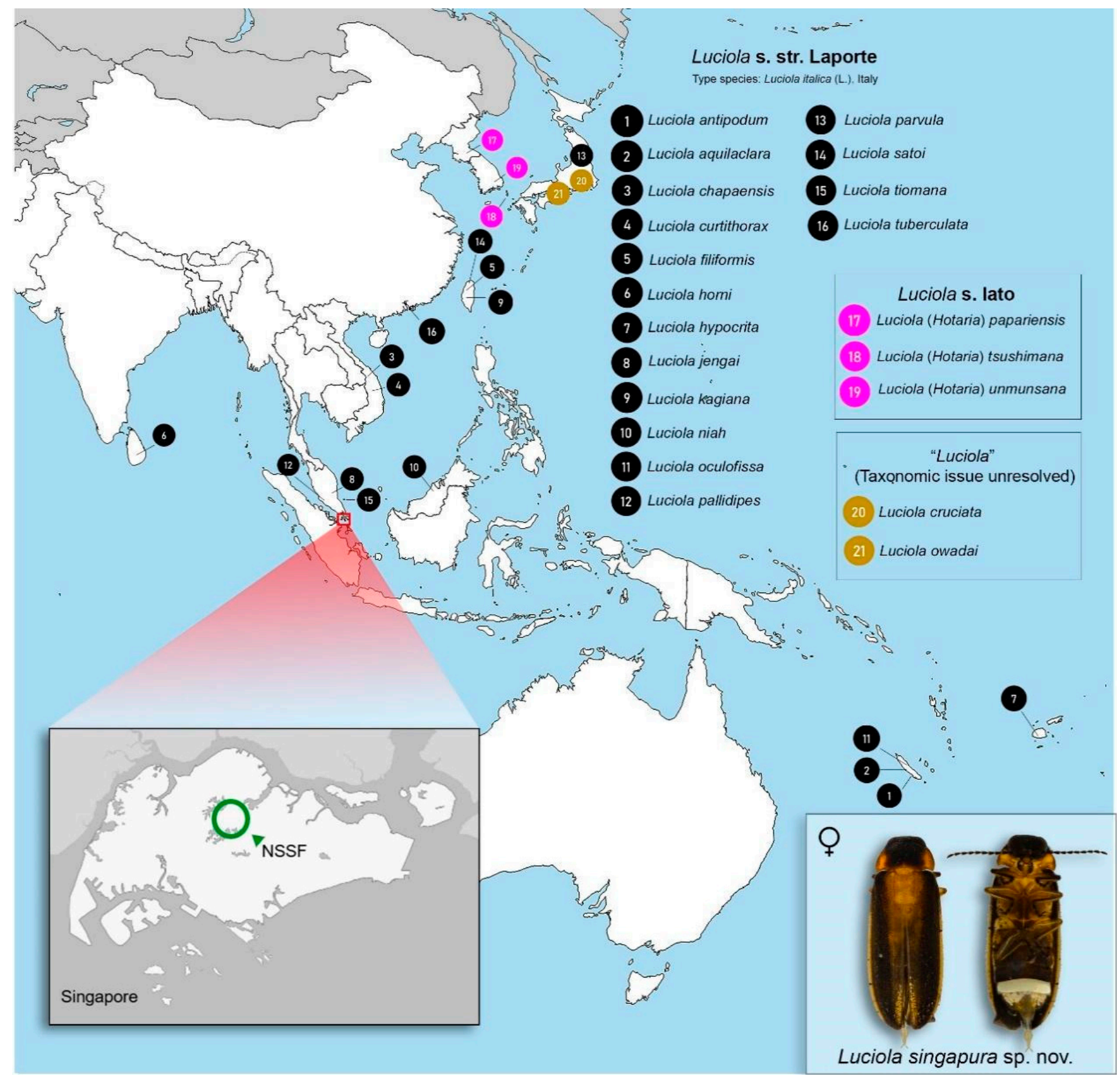

Figure 1. Map of Singapore showing the location of Luciola singapura Jusoh \& Ballantyne sp. nov. in the Nee Soon Swamp Forest (NSSF) (inset). Numbered dots represent type localities of Luciola species in Asia and the Pacific islands that were examined and/or analysed in this study. List of species in Table S1.

\subsection{Morphological Analysis}

We conducted morphological examinations using an Olympus SZ51 (Olympus Corporation, Tokyo, Japan) microscope and basic dissection materials. Characters assessed, abbreviations, and dissection of abdominal features follow [3] and are summarized in Table 1. We also included references to diagrams in previously published work where appropriate. Diagnostic morphological characters were checked and compared against 16 published type specimens of Luciola from the SE Asian and Australia-Pacific region (Figure 1; Table S1). We imaged specimens using the Dun Inc. Passport II Photomicrography imaging system (with $65 \mathrm{~mm}$ MPE Canon Lens) (Dun, Inc., Virginia, USA), and image post-processing was done in Adobe Lightroom (Adobe Inc., California, USA) and stacked in Zerene Stacker (Zerene Systems LLC, Washington, DC, USA). 
Table 1. Abbreviations and definitions of morphological characters examined in this study.

\begin{tabular}{|c|c|}
\hline Character & Definition \\
\hline a & $\begin{array}{l}\text { aedeagal dimension, distance from dorsal base of the lateral lobes to the apex } \\
\text { of the median lobe (see b); expressed as b/a [15] (p. 25, Figure 25; p.37, } \\
\text { Figure 104) }\end{array}$ \\
\hline A & pronotal dimension measured from above; width across anterior third \\
\hline ASD & distance between antennal sockets \\
\hline ASW & antennal socket greatest diameter \\
\hline $\mathrm{b}$ & $\begin{array}{l}\text { aedeagal dimension, distance from the dorsal base of the lateral lobes to the } \\
\text { apex of the lateral lobes (see a); expressed as b/a [15] (p. 25, Figure 25; p.37, } \\
\text { Figure 104) }\end{array}$ \\
\hline B & pronotal dimension measured from above; width across middle \\
\hline $\mathrm{BL}$ & body length measured as median length of pronotum plus length of elytron \\
\hline $\mathrm{C}$ & pronotal dimension measured from above; width across posterior third \\
\hline FS & antennal flagellar segments \\
\hline GHW & greatest head width (across eyes, measured parallel to ASD) \\
\hline $\mathrm{L}$ & length \\
\hline Legs 1,2 etc & $\begin{array}{l}\text { legs and parts of legs are referred to by their segment number e.g., legs } 1 \text { are } \\
\text { prothoracic legs; tarsi } 2 \text { = mesothoracic tarsi; femora } 3 \text { = metathoracic femora. }\end{array}$ \\
\hline LL & lateral lobes, aedeagus \\
\hline $\mathrm{LO}$ & light organ \\
\hline ML & median lobe of the aedeagus \\
\hline $\mathrm{MN}$ & mesonotal plates \\
\hline MS & mesoscutellum \\
\hline MPP & median posterior projection ventrite 7 male only \\
\hline PLP & posterolateral projections ventrite 7 male only \\
\hline SIW & $\begin{array}{l}\text { smallest interocular width (measured horizontally and may be on the same } \\
\text { level as ASD, ASW, or above it if the eyes are closer there) }\end{array}$ \\
\hline T7, 8 etc. & abdominal tergites \\
\hline V6, 7 etc. & abdominal ventrites, referred to by actual, not visible number \\
\hline W & width \\
\hline $\mathrm{W} / \mathrm{L}$ & width/length \\
\hline$x$ & times \\
\hline
\end{tabular}

\subsection{DNA Extraction, Sequencing and Bioinformatics}

For this study, we extracted genomic DNA (gDNA) from three firefly specimens from Singapore (Pyrocoelia fumigata Gorham, Pteroptyx valida Olivier and Luciola sp. 2; see Table S2) using the QIAamp 96 DNA QIAcube HT Kit (QIAGEN, Germany) on the QIAcube platform following an overnight digest of the entire specimen according to the manufacturer's instructions. The gDNA of firefly samples were then pooled with other species (non fireflies) across three libraries, with each library consisting of DNA from 100 species and sequenced on an Illumina Hiseq 2500 250-bp paired-end lane (Illumina, San Diego, USA) following library preparation with a NEBNext Ultra ${ }^{\mathrm{TM}}$ II DNA Library Prep Kit (NEB, Ipswich, USA) at the Genomic Institute of Singapore (Singapore). A total of 340 million reads were generated from the total run, with each library receiving an average of 113 million reads. Exact coverage is difficult to determine because of the pooling of multiple species in the same library. However, from our estimation, a total of 17.5 million reads were obtained from $\sim 300$ species, which gives an average $3.7 \times$ coverage for the mitogenomes. After 
sequencing, Trimmomatic v.0.39 [27] was used for adapter trimming and a BLAST search was conducted on the reads against a reference database of full Lampyridae mitochondrial genomes from NCBI GenBank (see Data S1) to filter out non-mitochondrial reads. The filtered reads were then assembled using four different assemblers: SPAdes v.3.13 [28] (-meta, -k 21,33,55,77), Ray v.2.1.1 [29] (-k 61, -minimumseedlength 100 -minimumcontiglength 1000), IDBA-UD [30] (-mink 60 -maxk 150) and CLCGenomicsWorkbench v.8.0.3. For IDBA-UD, we performed additional quality filtering using PRINSEQ [31] before assembly. The assembled contigs were then merged into supercontigs in Geneious R11 [32] via the De Novo Assemble function (minimum overlap: 1000, 1\% maximum mismatches per read). We annotated the mitochondrial genomes with Geneious' Live Annotate and Predict function using annotated lampyrid mitogenomes from NCBI GenBank and extracted the coding genes as well as rRNA sequences.

\subsection{Genetic Data and Phylogenetic Analyses}

In addition to the mitogenomes sequenced in this study, we also obtained published mitogenomes from eight closely related genera within the subfamily Luciolinae (Abscondita, Aquatica, Asymmetricata, Curtos, Inflata, Pteroptyx, Pygoluciola and Sclerotia) and partial mitochondrial fragments of Cytochrome c oxidase subunit 1 (COX1) and Cytochrome c oxidase subunit 2 (COX2) from 34 species to fill-in sampling gaps and increase taxonomic coverage. The mitogenomes of Pyrocoelia rufa and P. fumigata from the subfamily Lampyrinae were used as outgroups. All sequences used in this study and their associated GenBank accession numbers are presented in Table S2.

Sequences were aligned separately using MAFFT v7 [33] and subsequently concatenated using AMAS [34]. Pairwise uncorrected $p$-distances of the COX1 gene were calculated using MEGA-X [35]. The "complete deletion" option was used for missing data, while other options were left at default settings. We then performed phylogenetic analyses of concatenated data using maximum likelihood (ML) and Bayesian Inference (BI). The ML analysis was implemented in the program IQ-TREE v2.1.1 [36] (partitioned by marker). The best-fit substitution model for each partition was determined using ModelFinder [37] and a 50\% majority-rule consensus tree was constructed from 1000 ultrafast bootstrap replicates [38]. To parse out the effects of missing data, we also performed an IQ-TREE analysis on COX1 sequences only. The BI phylogeny was estimated using BEAST2 [39], implemented through the CIPRES portal [40]. Substitution models for each partition were averaged using bModelTest [41] and the relaxed log-normal and Yule models were used as the clock and tree priors respectively. Two independent Markov chain Monte Carlo (MCMC) chains were executed at 20,000,000 generations each and assessed for convergence using Tracer [42]. A maximum clade credibility tree was obtained from the converged and combined posterior distributions after discarding the first $10 \%$ of sampled trees as burn-in.

\section{Results}

\subsection{Morphology}

Luciola sp. 2 has a distinctive pale-colored pronotum with median dark marking; a character that is shared with several Luciola species. However, it can be distinguished from (a) Luciola curtithorax Pic by the ML length to LL; (b) L. filiformis Olivier and L. parvula by the absence of hind wings or brachelytral in females; (c) L. horni by apices of LL narrowed and strongly divergent and anterolateral arms longer than abdominal tergite 8 (T8) entire posterior portion, the posterior margin of which is rounded [3] (p. 92, Figure 268). Luciola sp. 2 also differs from the following ten Luciola s. str. species in (a) biogeographic distribution-L. italica is a European species and the following four species are known only from the Pacific islands: L. antipodum, L. aquilaclara, L. hypocrita and L. oculofissa (Figure 1); (b) distinctive ecological state-two species from East Asia: L. satoi occurs at high elevations (500-1600 m a.s.1.) in Taiwan [43] (p. 255) and L. tuberculata Yiu confined to specific mature woodlands and currently classified as endemic to Hong Kong [44]; (c) body length: Luciola sp. 2 is at least twice as small as L. chapaensis, L. jengai and L. kagiana (Table S1). 
Among SE Asian Luciola species, L. sp. 2 can be distinguished by having a pronotum with a median dark marking and in particular from L. niah by not having pale dorsal coloration with black elytral apices [3] (p. 95, Figures 284-287); the separation of aedeagal LL along their inner dorsal length and the ML length in comparison with LL [3] (p. 95, Figures 288-291 Figure 288 Figure 289 Figure 290 Figure 291); L. pallidipes by the nonuniform dorsal coloration [3] (p. 98, Figure 296); smaller interocular distance [3] (p. 98, Figure 301) and median anterior margin of aedeagal sheath tergite not apically squarely truncated [3] (p. 99, Figure 305); L. tiomana by the posterolateral corners of the pronotum being obtusely rounded [3] (p. 101, Figure 301), median posterior margin of T8 slightly emarginated and median anterior margin of aedeagal sheath tergite prolonged and apically truncated [3] (p. 101, Figure 314).

\subsection{Genetic Distance, Phylogenetic Analyses, and Divergence Times}

A total of 15 mitochondrial markers were sequenced (12S, 16S, ATP6, ATP8, COX1, COX2, COX3, Cytochrome- $b, N D 1, N D 2, N D 3, N D 4, N D 4 L, N D 5$, and ND6) and the final concatenated sequence matrix consisted of 13,602 base pairs. The uncorrected $p$-distances (based on COX1) among Luciola sp. 2 and closely-related taxa were consistent with interspecific distances among other lucioline taxa (12.5-22.0\%), while $p$-distances among L. umunsana, L. tsushimana and L. papariensis were markedly lower (4.4-6.2\%). Distances between Aquatica leii and A. ficta were $0 \%$, indicating that these taxa could be conspecific (Figure 2).

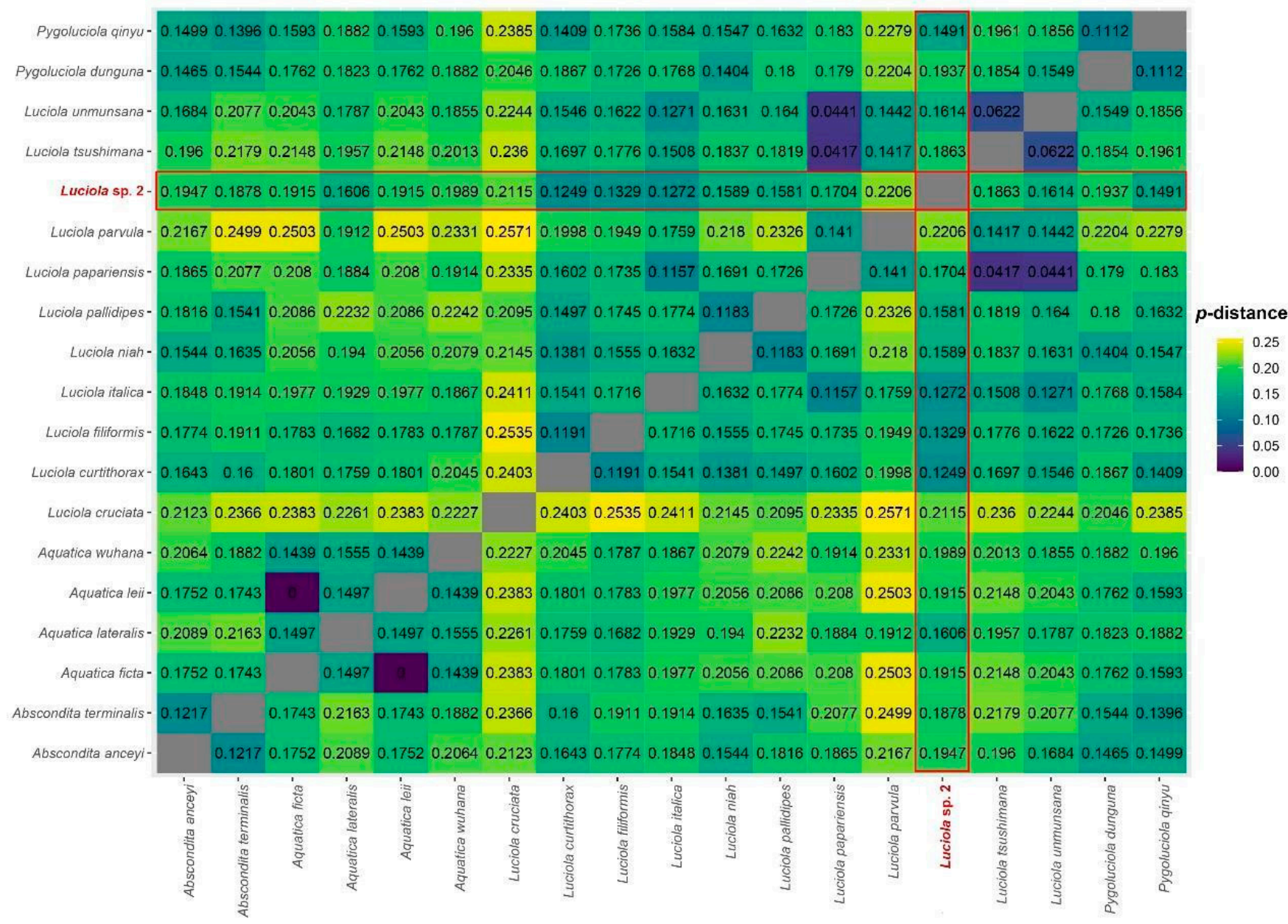

Figure 2. Heatmap of uncorrected p-distances among Luciola sp. 2 and closely-related taxa based on COX1. 
Both ML and BI topologies inferred largely similar topologies except for minor differences within the Pteroptyx/Inflata clade, which also had weak support in both phylogenies (Figure 3). Despite similar topologies, branch support along the backbone of the BI phylogeny was significantly stronger compared to the ML phylogeny. The genus Luciola was paraphyletic with strong support-L. owadai and L. cruciata from Japan were recovered as the sister lineage to the genus Aquatica, while other Luciola species formed a clade that was sister to the Pygoluciola + Abscondita clade. The latter Luciola clade corresponds to Luciola s. str. proposed by Ballantyne and Lambkin [8]. The genus Pteroptyx was also paraphyletic with regard to the genus Inflata. Luciola sp. 2 formed a clade with L. curtithorax and L. filiformis with high support in both phylogenies. The ML phylogeny based purely on COX1 sequences was weakly supported and produced different topologies with regard to the genera Sclerotia, Pteroptyx, Curtos, and Asymmetricata, while relationships among Aquatica, Abscondita, Pygoluciola, and Luciola remained the same (albeit with weaker support). Luciola cruciata was also recovered as the sister lineage to the Aquatica clade with strong support. Similarly, L. sp. 2 was also recovered as the sister lineage to L. filiformis + L. curtithorax.

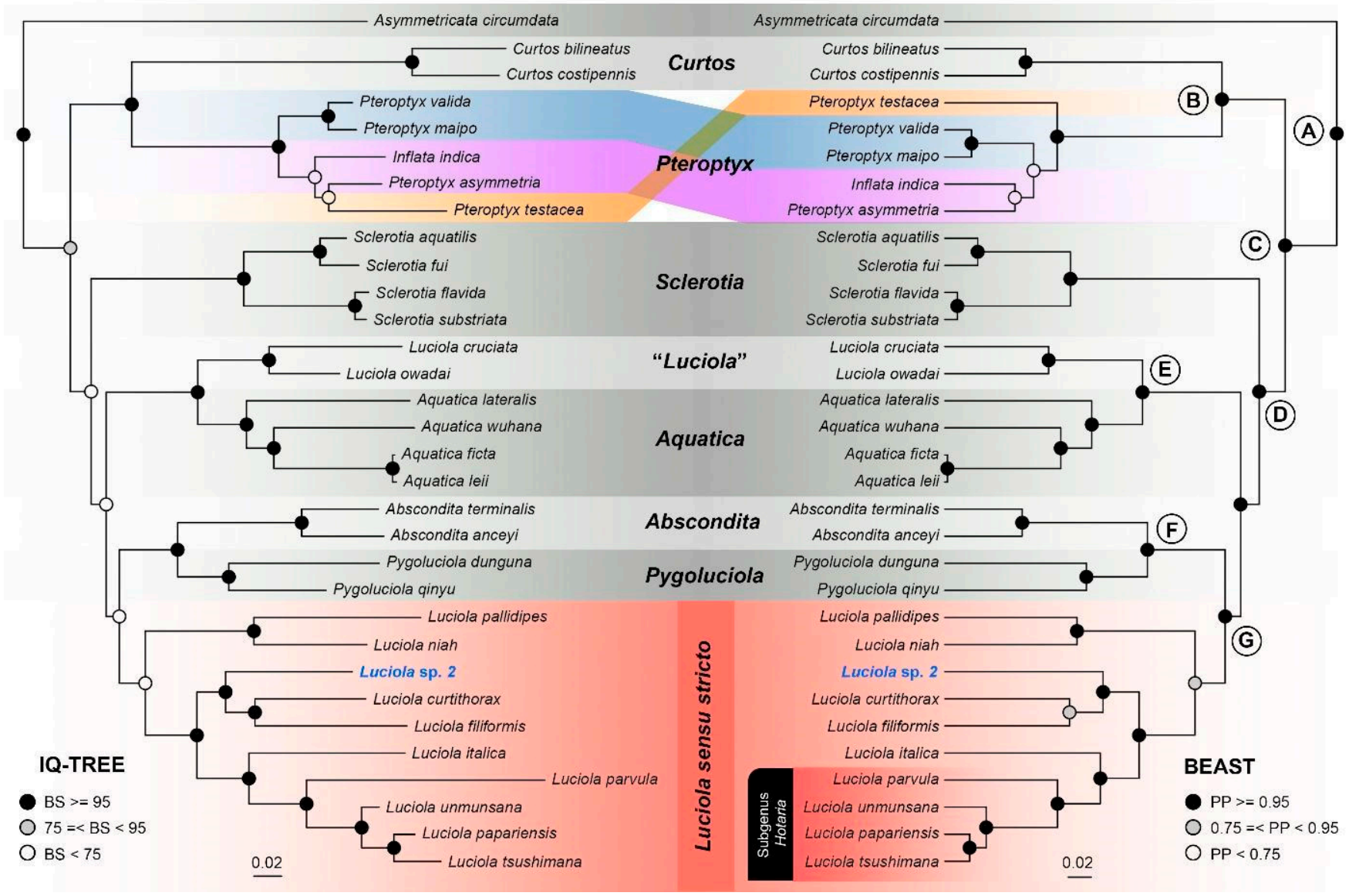

Figure 3. Maximum likelihood (left) and Bayesian (right) phylogenies based on 13,602 bps of mitogenomic data.

\subsection{Systematics}

Our results demonstrate that Luciola sp. 2 represents a distinct evolutionary lineage that is genetically and morphologically distinct from other congeners and is thus described as a new species below:

Luciola singapura Jusoh and Ballantyne sp. nov.

LSID: urn:Isid:zoobank.org:act:A963B320-8889-4FEC-B152-21E3EFAB76F9

English name: Singapore firefly

Malay name: Kunang-kunang Singapura 


\subsubsection{Type Material}

Holotype, male, in ethanol, with genitalia in a separate vial. Singapore: Nee Soon Swamp Forest, 18 January 2019, 9:00-9:20 p.m., coll. T.W. Wong, S.H. Chan and W.F.A. Jusoh, catalogue no. ZRC_ENT00034035. Paratypes, 1 female, 6 males: All paratypes bear the same locality label as the holotype, i.e., Singapore: Nee Soon Swamp Forest or "Nee Soon Pipeline (Upp Peirce) Freshwater Swamp"; 18 January 2019, 8:30-9:00 p.m., coll. T.W. Wong, S.H. Chan and W.F.A. Jusoh, ZRC_ENT00034034 (1 female, ethanol-preserved specimens); 11 January 2019, 8:30-9:00 p.m., coll. T.W. Wong, S.H. Chan and W.F.A. Jusoh, catalogue no. ZRC_ENT_00034033, sample ID: WFA-2149 (1 male, ethanol-preserved specimen); 22 January 2010, coll. Yeo Suay Hwee and S.H. Chan, ZRC_ENT00034042 (1 male; ethanol-preserved specimen, sample ID: NS010 (sequenced in this study); 22 January 2010, coll. S.H. Chan, 22:15 hrs, catalogue no. ZRC_ENT00034043 (1 male, dry preserved, pinned specimen); 18 January 1990, coll. Y.H. Koo and P.K.L. Ng, catalogue nos. ZRC_ENT_00000010, ZRC_ENT00034044 (2 males, dry preserved specimen, cardmounted); 28 Dec 1989, coll. Y.H. Khoo and K. Snyder, catalogue no. ZRC_ENT00034045 (1 male, dry preserved specimen, card-mounted).

\subsubsection{Diagnosis}

A small species (less than $5 \mathrm{~mm}$ long) with distinctive dorsal coloration of black head, orange to yellowish brown with dark markings on pronotum, and orange to yellowish brown elytra which have diffuse darker brown to black markings towards the apex, with paler basal markings restricted to basal area near suture and an accumulation of whitish fat body along apex of suture and round elytral apex. Metasternum with median dark marking.

\subsubsection{Description}

Males. 4.44-4.71 mm long. Color (Figure 4A,B): dorsal coloration not concolorous (note that type specimens that were recently collected and preserved in $70 \%$ ethanol slightly differ in color compared to dry preserved specimens); pronotum orange to yellowish brown (either orange, Figure 4A or yellowish brown Figure 4B) with median darker markings; mesonotal plates (MN), mesoscutellum (MS) and elytra orange to yellowish brown with elytral apices black or dark brown; elytra semitransparent and underlying hind wings may confuse interpretation of color; head black, antennae and palpi dark brown to black; venter of thorax yellow (or yellow orange) with median dark brown to black marking which reaches the anterior but not the posterior pronotal margin, lateral margin orange (Figure 4A, arrowed; Figure 4B, inset), basal abdominal ventrites (except ventrite 6 (V6) and ventrite 7 (V7)) and abdominal tergites dark brown to black; legs yellowish brown with tibiae and tarsi dark brown (legs yellow, tarsi light brown); Light organ (LO) creamy white (Figure 4A). Pronotum (Figure 4B, inset; Figure 4C): slightly convex-sided; lateral margins diverging laterally along most of their length $(\mathrm{B}>\mathrm{A}, \mathrm{C})$; width subequal to humeral width; antero- and posterolateral corners rounded obtuse. Elytron: subparallel sided with narrow pale margins. Accumulation of fat body along apex of suture and round elytral apex (Figure 4A,B arrowed). Head (Figure 4C): moderately well exposed in front of pronotum; minimal depression between eyes; greatest head width (GHW) $8 \mathrm{X}$ smallest interocular width (SIW); distance between antennal sockets (ASD) much less than antennal socket greatest diameter (ASW) (sockets are almost contiguous). Antennae: longer than GHW but not as long as $2 \mathrm{X} \mathrm{GHW}$; 11 segments, elongate slender, scape longer than antennal flagellar segments (FS) (Figure 4C). Mouthparts: apical labial palpomere laterally flattened with inner edge dentate. Abdomen (Figure 4A,B,D): LO occupying entire area of V6, 7; V7 a little longer than wide, posterior margin acute, no posterolateral projections (PLP), no median posterior projection (MPP); Tergite 8 (Figure 4D) with anterolateral arms elongate slender slightly shorter than entire posterior portion which is rounded and without median emargination. Aedeagal sheath (Figure 4A,B): apical margin of sheath sternite narrowly prolonged and medianly not emarginated and hairy; median anterior margin of sheath 
tergite prolonged and apically truncated. Aedeagus (Figure 4B): apices of LL narrow; LL about equal to ML, leaf-like, closely approach along median dorsal line.
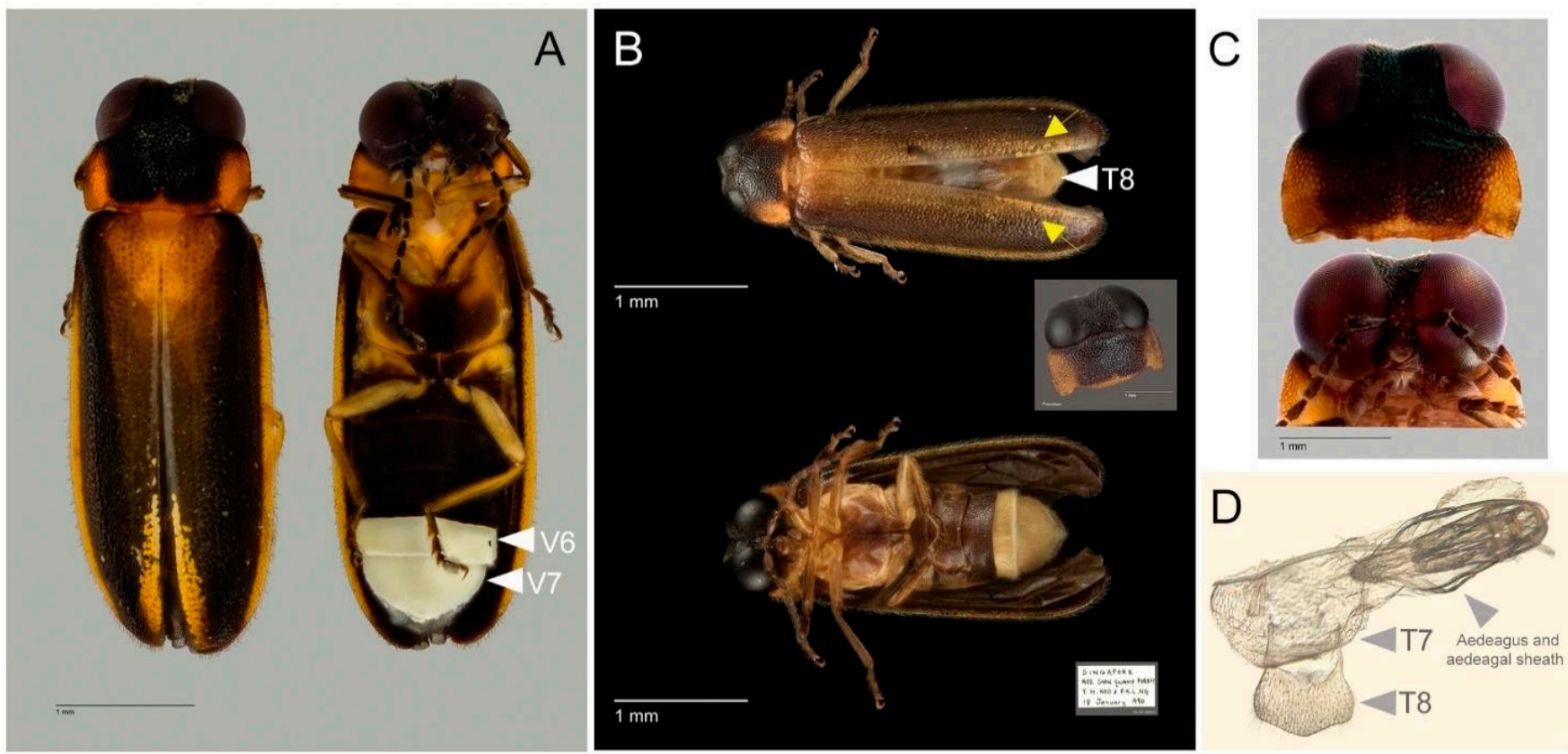

Figure 4. Males of Luciola singapura sp. nov. Habitus (A,B), head and pronotum (C); Tergite 8 after dissection (D). (A). Holotype male, from recent collection preserved in ethanol, light organ (LO) located on ventrite 6 (V6) and ventrite 7 (V7), presence of fat body along apex of suture, arrowed; (B). Habitus of paratype male. Coloration of paratype male collected 30 years ago preserved as dry specimen, arrow indicated presence of fat body along suture, tergite 8 (T8) from dorsal view and pronotum (inset); (C). Top: Head and pronotum of paratype male, below: Mouthpart and some parts of antenna; (D). Dissection parts of holotype male: tergites 7-8 indicated with aedeagus and aedeagal sheath.

Female (Figure 5C-E). $3.93 \mathrm{~mm}$ long. Associated by its occurrence in the same habitat within the same time of sampling, similarity of distinctive color patterns and identical DNA barcode with the males. Macropterous and capable of flight. Colored as for male except LO in V6; and V7, 8 are semitransparent, whitish fat reaching anteriorly and to sides but not reaching to posterior margin of $\mathrm{V} 7$, posterior margin of $\mathrm{V} 7$ widely emarginated (Figure 5C,E, arrowed). Antennae: 11 segmented with elongate scape which is expanded in apical half, pedicel slightly shorter than scape and antennal flagellar segment 1 (FS1), all flagellar segments elongate slender; no flagellomeres expanded. No bursa plate and spermatophore gland observed (Figure 5E).

\subsubsection{Etymology}

The specific epithet, singapura, is the Malay name for the country Singapore, which is the type locality of the new species.

\subsubsection{Distribution}

Known only from the type locality of NSSF, Central Catchment Nature Reserve in Singapore (see also [24], p. 115, Figure 1) but may also occur in other parts of the island where habitat is suitable.

\subsubsection{Ecology}

The habitat is a swampy area adjacent to the water pipeline system (Figure 6A,B) with dense vegetation, damp leaf litter, and high soil moisture. Chan and colleagues observed the adults congregating within a very small area at a specific location, most of which were perching and flashing on a species of fern identified as Blechnum finlaysonianum Wall. (Figure 6C). Some individuals were observed flying low while emitting flickering yellow 
flashes among shrubs and at the fringe of the forest between 8:00 p.m. and 10:15 p.m. No larvae were spotted.
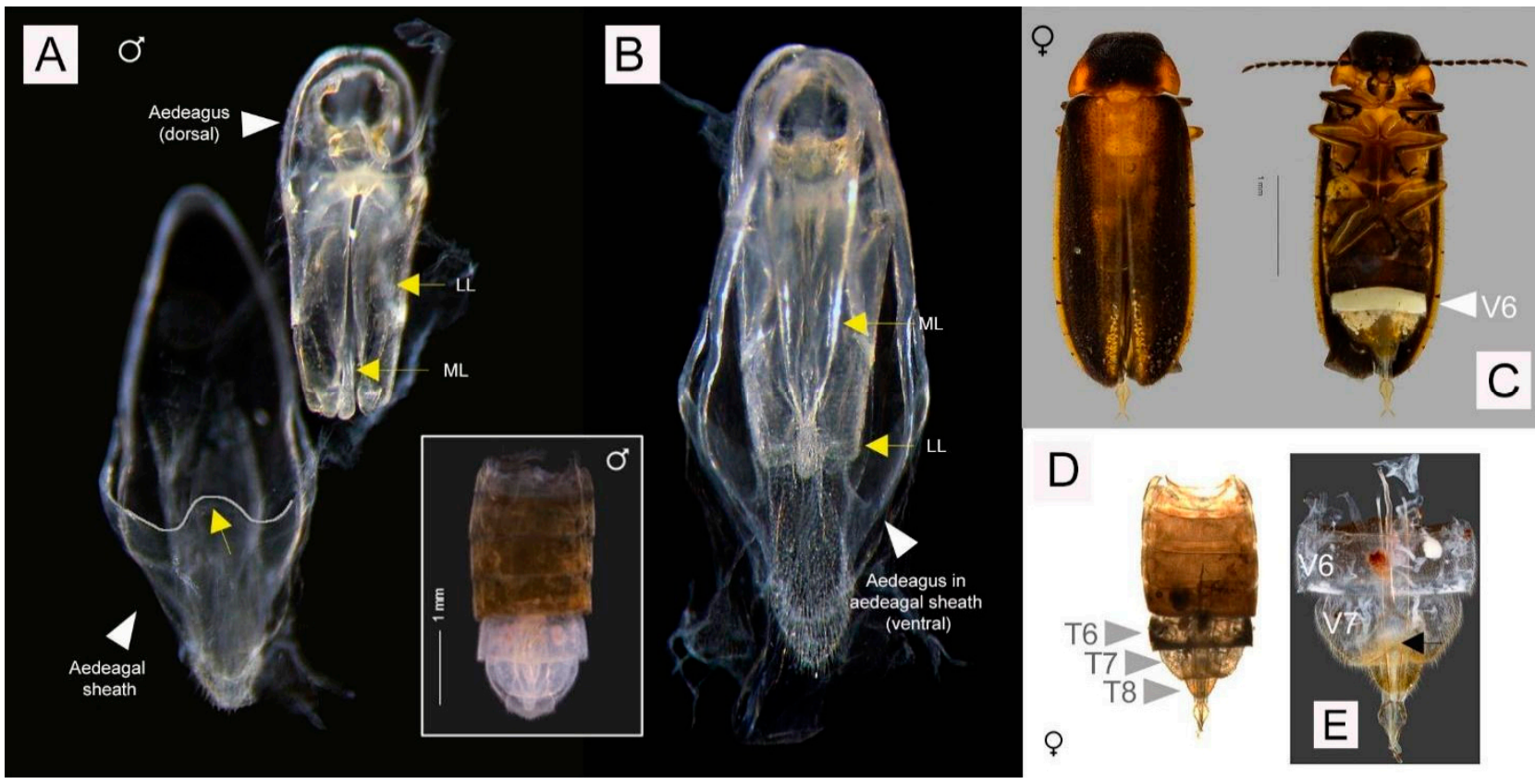

Figure 5. Aedeagal and aedeagal sheath of male (A,B) and diagnostic characters of female (C-E) of L. singapura sp. nov.; (A). Aedeagal sheath, dorsal view, median anterior margin of sheath tergite prolonged and apically truncated, outlined and arrowed; (B). Aedeagus, dorsal view and ventral view with arrow indicated median lobe (ML) and lateral lobes (LL); Inset: dorsal view of male abdominal tergites showing aedeagus with aedeagal sheath and tergite 8 still intact; (C). Habitus, dorsal and ventral view, LO on V6; (D). Dorsal view (after tissue clearing, before dissection), tergites 6-8 indicated; (E). Ventral view, dissected part, arrow showing posterior margin of V7 widely emarginated.

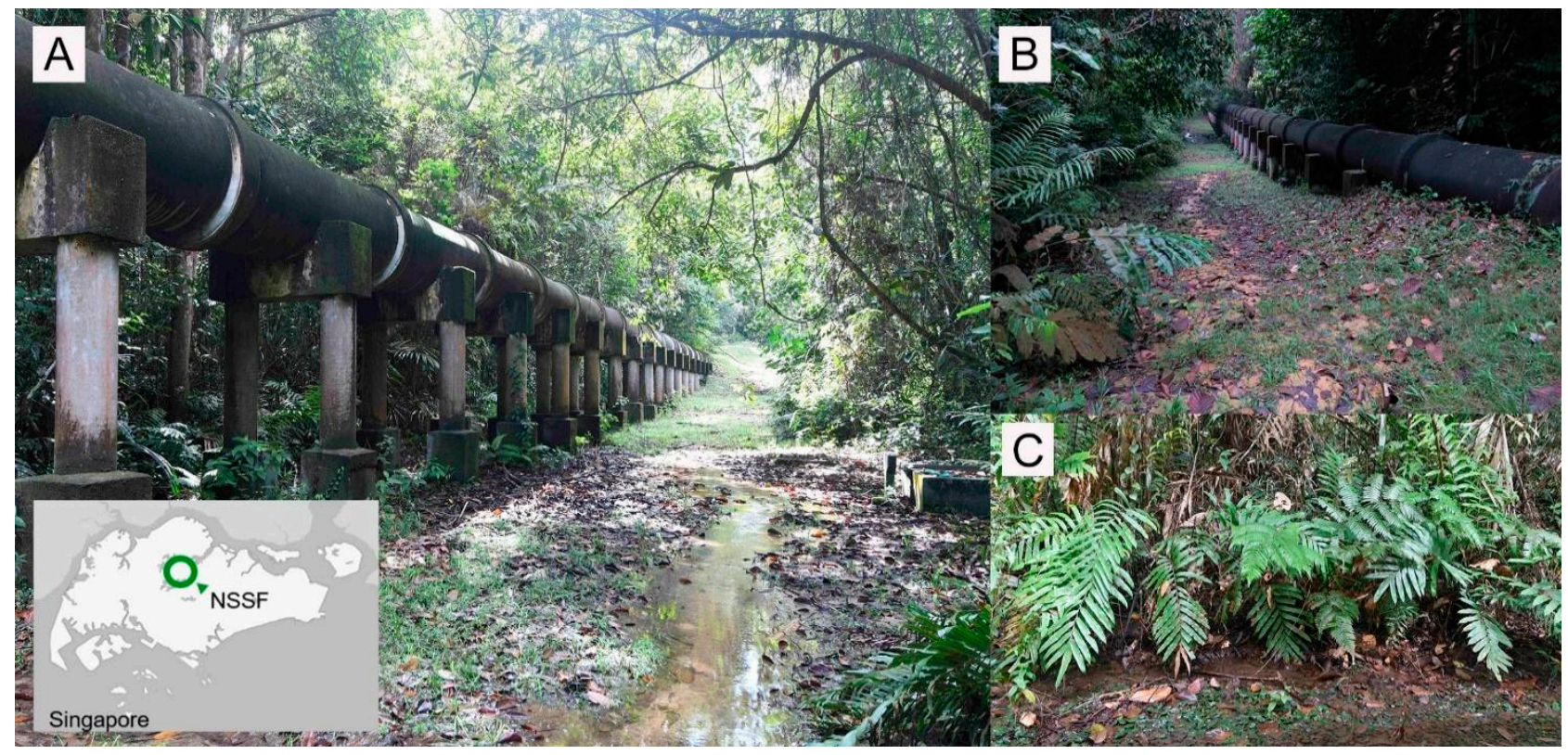

Figure 6. Habitat at Nee Soon Swamp Forest in Singapore (map, inset) where L. singapura was found; (A,B). The freshwater swamp is situated within the water catchment along a water supply pipeline; (C). Adult fireflies of L. singapura were observed flying around and/or perching among shrubs beneath the pipeline with the majority of them perched on ferns. 


\section{Discussion}

\subsection{Phylogenetic Relationships and Evolutionary History}

Our analyses strongly supported the paraphyly of Luciola cruciata and L. owadai that was inferred as the sister lineage to the genus Aquatica as opposed to other Luciola species. Similar to the genus Aquatica, larvae of L. cruciata and L. owadai are also aquatic (as opposed to larvae of other Luciola species which are semi-aquatic or terrestrial) $[2,3,14]$, thereby providing additional support for their phylogenetic affinity with Aquatica as opposed to Luciola. Our results, which are also consistent with previous studies, unequivocally demonstrate that L. cruciata and L. owadai do not belong to the genus Luciola and should either be subsumed under the genus Aquatica or recognized as a new genus. Consequently, we formally remove L. cruciata and L. owadai from the genus Luciola and provisionally consider them as incertae sedis ("Luciola") pending future investigation. Henceforth, all references to the genus Luciola exclude these two taxa.

Prior to our mitogenome-based phylogenetic analyses, the subfamily Luciolinae had been subjected to several phylogenetic studies, the most comprehensive of which performed maximum parsimony (MP) and BI analyses of concatenated molecular (25 taxa) and morphological data (158 taxa) [3,15]. In general, the MP analysis produced a topology similar to ours, but the BI analysis produced slightly different relationships. In our analysis, the genus Inflata was embedded within Pteroptyx (albeit with low support) as opposed to being reciprocally monophyletic with the genus Pteroptyx as inferred by [1,15]. Inflata is a monotypic genus that closely resembles Pteroptyx species in morphology, particularly of Group II (non-deflexed elytra + MFC + entire light organ (ELO), as defined by [45]) except that Inflata possesses entire LOs in V7 without the bulbous ML. Due to poor branch support, ambiguous morphological characters, and limited samples of Pteroptyx species assessed in this study, the phylogenetic placement and generic status of Inflata remain uncertain and would likely require additional molecular data to resolve. Concerning the similarity in DNA sequences of Aquatica leii and A. ficta, a re-examination of voucher specimens is necessary to determine whether those sequences have been misidentified.

For Luciola species under the subgenus Hotaria sensu McDermott, our analyses showed that they form a derived subclade within Luciola, thereby supporting their status at the subgenus rank as demonstrated by [22]. The type species of the subgenus Hotaria, L. parvula forms a clade with three other species, L. unmunsana, L. papariensis and L. tsushimana, which according to our results, are part of Luciola s. str. Morphologically, these three species share many similarities, which makes taxonomic identification at the species level challenging even for experienced taxonomists. Our results were not able to accept or reject the synonymies of L. papariensis and L. tsushimana with L. unmunsana as suggested by [23]. Luciola unmunsana, L. papariensis, and L. tsushimana were moderately divergent from each other $(4-6 \%$; see $[20,22]$ for more detailed discussions on this group). To exacerbate matters, the type specimens of L. unmunsana and L. papariensis are lost [3] (p. 104). We, therefore, refrain from making any taxonomic changes to these three species other than provisionally recognizing them as part of Luciola s. str. (see 4.2).

\subsection{Updated Notes on the Species of Luciola s. str. Laporte throughout the SE Asian and Australopacific Region}

With the description of Luciola singapura sp. nov., there are now 53 nominal species in the genus Luciola throughout the SE Asian and Australopacific region including species from Luciola s. str. Laporte and Luciola s. lato sensu Ballantyne. We expand the definition of Luciola s. str. in this region to comprise 20 species including the new species, Luciola singapura sp. nov. The provisional inclusion of Luciola jengai (see remarks in [3], p. 96), L. papariensis, L. tsushimana, and L. unmunsana may change following future taxonomic investigations.

Luciola s. str. Laporte:

1. antipodum (Bourgeois, 1884) [46]

2. aquilaclara Ballantyne, 2013 in [8] 


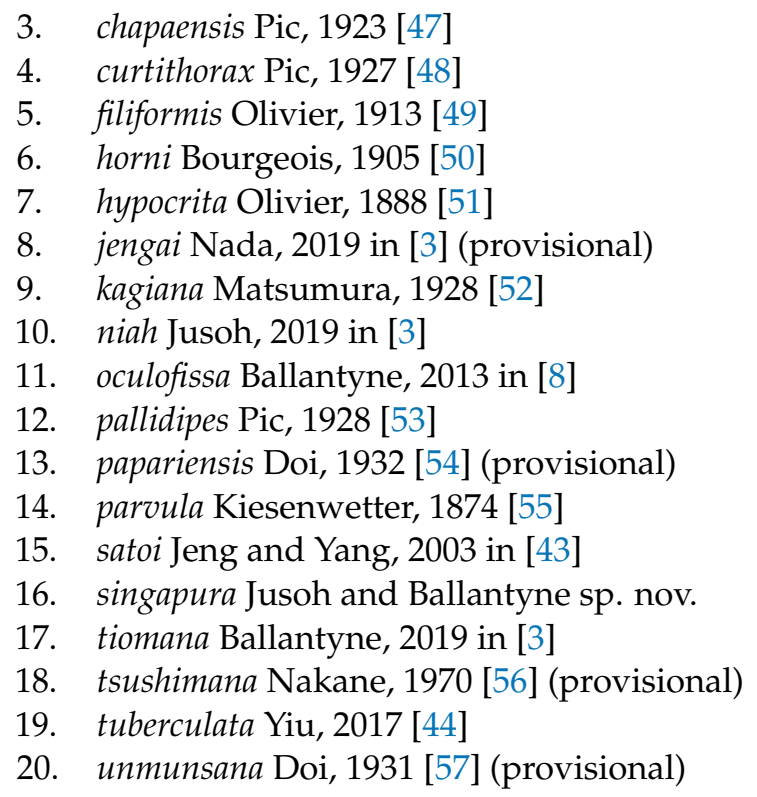

\subsection{Status and Conservation of Fireflies in Singapore}

Hitherto, Singapore has 14 species of fireflies, including Luciola singapura sp.nov. [24,25,58]. The list also comprises several morphospecies (e.g., Curtos sp., Diaphanes sp., Stenocladius sp.) from previous surveys $[24,58]$ and three type specimens from the non-luminous firefly group deposited in the Muséum national d'Histoire naturelle (MNHN) in Paris (Ototreta bakeri Pic, Lucidina wallacei Pic and Flabellotreta inapicalis Pic) collected from Singapore [25]. The Comtesse's firefly (Pteroptyx bearni Olivier), which is a well-known congregating firefly species in SE Asian mangroves has not been sighted in Singapore since 1909 and is assumed to be extirpated [25]. The following five species have been observed in primary forest, secondary forest, freshwater swamp, mangrove, grassland, and scrubland habitats: Abscondita pallescens (Gorham), Colophotia praeusta (Eschscholtz), Pteroptyx malaccae Gorham, Pteroptyx valida Olivier, and Pyrocoelia fumigata Gorham, of which only P. valida is listed as endangered (EN) in the Singapore Red Data Book [59].

Luciola singapura sp. nov. is a rare species that is only known from the type locality, which is a freshwater swamp forest within the Central Catchment Nature Reserve. More studies are needed to determine if this species is a freshwater swamp specialist, or whether it could also occur in other habitats. Although the type locality is legally protected from development and clearing, the long-term protection of this species will require a deeper understanding of its ecology and distribution, both of which are lacking.

\section{Conclusions}

The discovery of a new species of firefly from the last remaining freshwater swamp forest in Singapore - one of the most developed and urbanized countries in the world-highlights the importance of continued biodiversity research in the region. This study also underscores the utility of molecular approaches to resolve taxonomic problems and better understand the evolutionary history of fireflies.

Supplementary Materials: The following are available online at https://www.mdpi.com/2076-2 615/11/3/687/s1. Table S1: Diagnostic morphological characters of 17 species of Luciola s. str. found in Asia and the Pacific Islands, including Luciola sp. 2.; Table S2: List of genetic samples used in this study and their corresponding GenBank accession numbers; Data S1: GI numbers of Lampyridae from NCBI GenBank used for BLAST database; Sequence alignment (Nexus format) and all phylogenetic trees (Newick format). 
Author Contributions: Conceptualization, W.F.A.J., L.B. and K.O.C.; methodology, W.F.A.J., L.B., D.Y. and K.O.C.; formal analysis, W.F.A.J., L.B., D.Y. and K.O.C.; investigation, W.F.A.J., L.B., T.W.W., S.H.C., K.O.C., D.Y.; resources, S.H.C., T.W.W., B.N.; data curation, W.F.A.J., L.B., D.Y., K.O.C.; writing-original draft preparation, W.F.A.J., L.B.; writing-review and editing, L.B., K.O.C.; visualization, W.F.A.J., K.O.C. All authors have read and agreed to the published version of the manuscript.

Funding: This research received no external funding.

Institutional Review Board Statement: Not applicable.

Data Availability Statement: The data presented in this study are available as Supplementary Materials.

Acknowledgments: We thank Rudolf Meier, Lee Wan Ting, Yuen Huei Khee, and Arina Adom from the Evolutionary Biology Laboratory (NUS) for support and assistance in laboratory work. Field collection at NSSF was carried out under NParks research permit no.: NP/RP18-110.

Conflicts of Interest: The authors declare no conflict of interest.

\section{References}

1. Ballantyne, L.; Lambkin, C.L.; Boontop, Y.; Jusoh, W.F.A. Revisional studies on the Luciolinae fireflies of Asia (Coleoptera: Lampyridae): 1. The genus Pyrophanes Olivier with two new species. 2. Four new species of Pteroptyx Olivier and 3. A new genus Inflata Boontop, with redescription of Luciola indica (Motsch.) as Inflata indica comb. nov. Zootaxa 2015, 3959, 1-84. [CrossRef]

2. Ballantyne, L.A.; Lambkin, C.L.; Luan, X.; Boontop, Y.; Nak-Eiam, S.; Pimpasalee, S.; Silalom, S.; Thancharoen, A. Further studies on South Eastern Asian Luciolinae: 1. Sclerotia Ballantyne, a new genus of fireflies with back swimming larvae 2. Triangulara Pimpasalee, a new genus from Thailand (Coleoptera: Lampyridae). Zootaxa 2016, 4170, 201-249. [CrossRef]

3. Ballantyne, L.A.; Lambkin, C.L.; Ho, J.Z.; Jusoh, W.F.A.; Nada, B.; Nak-Eiam, S.; Thancharoen, A.; Wattanachaiyingcharoen, W.; Yiu, V. The Luciolinae of S. E. Asia and the Australopacific region: A revisionary checklist (Coleoptera: Lampyridae) including description of three new genera and 13 new species. Zootaxa 2019, 4687, 1-174. [CrossRef] [PubMed]

4. McDermott, F.A. Lampyridae. In Coleopterorum Catalogus Supplementa. Pars 9. Editio Secunda; Steel, W.O., Ed.; W. Junk: S'Gravenhage, The Netherlands, 1966; p. 149.

5. Ballantyne, L.; Fu, X.; Lambkin, C.; Jeng, M.L.; Faust, L.; Wijekoon, W.M.C.D.; Li, D.; Zhu, T. Studies on South-east Asian fireflies: Abscondita, a new genus with details of life history, flashing patterns and behaviour of Abs. chinensis (L.) and Abs. terminalis (Olivier) (Coleoptera: Lampyridae: Luciolinae. Zootaxa 2013, 3721, 1-48. [CrossRef]

6. Olivier, E. Coleoptera. Fam. Lampyridae. In Genera Insectorum. Fasc. 53; Wytsman, P., Ed.; Verteneuil \& Desmet: Bruxelles, Belgium, 1907; pp. 1-74.

7. Olivier, E. Pars 9. Lampyridae. In Coleopterorum Catalogus; Schenkling, S., Ed.; Junk, W.: Berlin, Germany, $1910 ;$ p. 68.

8. Ballantyne, L.A.; Lambkin, C.L. Systematics and phylogenetics of Indo-Pacific Luciolinae fireflies (Coleoptera: Lampyridae) and the description of new genera. Zootaxa 2013, 3653, 1-162. [CrossRef] [PubMed]

9. Ballantyne, L.A.; Menayah, R. Redescription of the synchronous firefly, Pteroptyx tener Olivier (Coleoptera: Lampyridae), of Kampung Kuantan, Selangor. Malayan Nat. J. 2000, 54, 323-328.

10. Ballantyne, L.A.; Lambkin, C. Lampyridae of Australia (Coleoptera: Lampyridae: Luciolinae: Luciolini). Mem. Queensl. Museum 2000, 46, 15-93.

11. Fu, X.; Ballantyne, L.; Lambkin, C. The external larval morphology of aquatic and terrestrial Luciolinae fireflies (Coleoptera: Lampyridae). Zootaxa 2012, 3405, 1-34. [CrossRef]

12. Ballantyne, L.A.; Lambkin, C. A phylogenetic reassessment of the rare S. E. Asian firefly genus Pygoluciola Wittmer (Coleoptera: Lampyridae: Luciolinae). Raffles Bull. Zool. 2006, 54, 21-48.

13. Ballantyne, L.A.; Lambkin, C.L. Systematics of Indo-Pacific fireflies with a redefinition of Australasian Atyphella Olliff, Madagascan Photuroluciola Pic, and description of seven new genera from the Luciolinae (Coleoptera: Lampyridae). Zootaxa 2009, 1997, 1-188. [CrossRef]

14. Fu, X.H.; Ballantyne, L.A.; Lambkin, C. Aquatica gen. nov. from mainland China with a description of Aquatica wuhana sp. nov. (Coleoptera: Lampyridae: Luciolinae). Zootaxa 2010, 2530, 1-18. [CrossRef]

15. Jusoh, W.F.A.; Ballantyne, L.; Lambkin, C.L.; Hashim, N.R.; Wahlberg, N. The firefly genus Pteroptyx Olivier revisited (Coleoptera: Lampyridae: Luciolinae). Zootaxa 2018, 4456, 1-71. [CrossRef] [PubMed]

16. Linnaeus, C. Systema Naturae per Regna Tria Naturae, Secundum Classes, Ordines, Genera, Species, Cum Characteribus, Differentiis, Synonymis, Locis. Editio Duodecima, Reformata. Tomus I. Pars II; Laur. Salvii: Holmiae, Stockholm, Sweden, 1767.

17. Ballantyne, L.A. Pygoluciola satoi, a new species of the rare S E Asian firefly genus Pygoluciola Wittmer from the Philippines (Coleoptera: Lampyridae: Luciolinae). Raffles Bull. Zool. 2008, 56, 1-9.

18. Ballantyne, L.A.; Lambkin, C. A new firefly, Luciola (Pygoluciola) Kinabalua, new species (Coleoptera: Lampyridae), from Malaysia, with observations on a possible copulation clamp. Raffles Bull. Zool. 2001, 49, 363-377.

19. Fu, X.H.; Ballantyne, L. Taxonomy and behaviour of lucioline fireflies (Coleoptera: Lampyridae: Luciolinae) with redefinition and new species of Pygoluciola Wittmer from mainland China and review of Luciola LaPorte. Zootaxa 2008, 1733, 1-44. [CrossRef] 
20. Choi, Y.S.; Bae, J.S.; Lee, K.S.; Kim, S.R.; Kim, I.; Kim, J.G.; Kim, K.Y.; Kim, S.E.; Suzuki, H.; Lee, S.M.; et al. Genomic structure of the luciferase gene and phylogenetic analysis in the Hotaria-group fireflies. Comp. Biochem. Physiol.-B Biochem. Mol. Biol. 2003, 134, 199-214. [CrossRef]

21. Ohba, N. Flash patterns and communication of the two ecotypes in Hotaria parvula. Sci. Rep. Yokosuka City Mus. 2000, 47, 1-22.

22. Han, T.; Kim, S.H.; Yoon, H.J.; Park, I.G.; Park, H. Evolutionary history of species of the firefly subgenus Hotaria (Coleoptera, Lampyridae, Luciolinae, Luciola) inferred from DNA barcoding data. Contrib. Zool. 2020, 89, 127-145. [CrossRef]

23. Kawashima, I.; Suzuki, H.; Satô, M. A check-list of Japanese fireflies (Coleoptera, Lampyridae and Rhagophthalmidae). Jpn. J. Syst. Entomol. 2003, 11, 225-262.

24. Chan, S.H.; Ballantyne, L.A.; Goh, C.A.L. Survey of species diversity, distribution and abundance of fireflies in Singapore. Lampyrid 2012, 2, 113-122.

25. Jusoh, W.F.A. Coleoptera: A very special firefly and other beetle stories. In Voyageurs, Explorateurs et Scientifiques: The French and Natural History in Singapore; Low, M.E.Y., Pocklington, K., Jusoh, W.F.A., Eds.; Lee Kong Chian Natural History Museum: Singapore, 2019; pp. 212-232.

26. Ng, P.K.L.; Lim, K.K.P. The conservation status of the Nee Soon freshwater swamp forest of Singapore. Aquat. Conserv. Mar. Freshw. Ecosyst. 1992, 2, 255-266. [CrossRef]

27. Bolger, A.M.; Lohse, M.; Usadel, B. Trimmomatic: A flexible trimmer for Illumina sequence data. Bioinformatics 2014, 30, 2114-2120. [CrossRef] [PubMed]

28. Bankevich, A.; Nurk, S.; Antipov, D.; Gurevich, A.A.; Dvorkin, M.; Kulikov, A.S.; Lesin, V.M.; Nikolenko, S.I.; Pham, S.; Prjibelski, A.D.; et al. SPAdes: A new genome assembly algorithm and its applications to single-cell sequencing. J. Comput. Biol. 2012. [CrossRef]

29. Boisvert, S.; Raymond, F.; Godzaridis, É.; Laviolette, F.; Corbeil, J. Ray Meta: Scalable de novo metagenome assembly and profiling. Genome Biol. 2012. [CrossRef] [PubMed]

30. Peng, Y.; Leung, H.C.M.; Yiu, S.M.; Chin, F.Y.L. IDBA-UD: A de novo assembler for single-cell and metagenomic sequencing data with highly uneven depth. Bioinformatics 2012. [CrossRef] [PubMed]

31. Schmieder, R.; Edwards, R. Quality control and preprocessing of metagenomic datasets. Bioinformatics 2011. [CrossRef]

32. Kearse, M.; Moir, R.; Wilson, A.; Stones-Havas, S.; Cheung, M.; Sturrock, S.; Buxton, S.; Cooper, A.; Markowitz, S.; Duran, C.; et al Geneious Basic: An integrated and extendable desktop software platform for the organization and analysis of sequence data. Bioinformatics 2012. [CrossRef]

33. Katoh, K.; Standley, D.M. MAFFT multiple sequence alignment software version 7: Improvements in performance and usability. Mol. Biol. Evol. 2013. [CrossRef]

34. Borowiec, M.L. AMAS: A fast tool for alignment manipulation and computing of summary statistics. PeerJ 2016, 4, e1660. [CrossRef] [PubMed]

35. Kumar, S.; Stecher, G.; Li, M.; Knyaz, C.; Tamura, K. MEGA X: Molecular evolutionary genetics analysis across computing platforms. Mol. Biol. Evol. 2018. [CrossRef]

36. Minh, B.Q.; Schmidt, H.A.; Chernomor, O.; Schrempf, D.; Woodhams, M.D.; Von Haeseler, A.; Lanfear, R.; Teeling, E. IQ-TREE 2: New models and efficient methods for phylogenetic inference in the genomic era. Mol. Biol. Evol. 2020, 37, 1530-1534. [CrossRef] [PubMed]

37. Kalyaanamoorthy, S.; Minh, B.Q.; Wong, T.K.F.; von Haeseler, A.; Jermiin, L.S. ModelFinder: Fast model selection for accurate phylogenetic estimates. Nat. Methods 2017, 14, 587-589. [CrossRef] [PubMed]

38. Hoang, D.T.; Chernomor, O.; von Haeseler, A.; Minh, B.Q.; Vinh, L.S.; Le, S.V. UFBoot2: Improving the ultrafast bootstrap approximation. Mol. Biol. Evol. 2018, 35, 518-522. [CrossRef] [PubMed]

39. Bouckaert, R.; Heled, J.; Kühnert, D.; Vaughan, T.; Wu, C.H.; Xie, D.; Suchard, M.A.; Rambaut, A.; Drummond, A.J. BEAST 2: A software platform for Bayesian evolutionary analysis. PLoS Comput. Biol. 2014. [CrossRef]

40. Miller, M.A.; Pfeiffer, W.; Schwartz, T. Creating the CIPRES Science Gateway for inference of large phylogenetic trees. In 2010 Proceedings of the Gateway Computing Environments Workshop, GCE 2010; Institute of Electrical and Electronics Engineers: New Orleans, LA, USA, 2010.

41. Bouckaert, R.R.; Drummond, A.J. bModelTest: Bayesian phylogenetic site model averaging and model comparison. BMC Evol. Biol. 2017, 17, 1-11. [CrossRef]

42. Rambaut, A.; Suchard, M.A.; Xie, D.; Drummond, A.J. Tracer v1.6. Available online: http://beast.bio.ed.ac.uk/Tracer2014 (accessed on 20 September 2020).

43. Jeng, M.-L.; Yang, P.-S.; Lai, J. Notes on the genus Luciola (Coleoptera, Lampyridae, Luciolinae) of Taiwan. Spec. Bull. Jpn. Soc. Coleopterol. 2003, 6, 247-262.

44. Yiu, V. A study of Rhagophthalmidae and Lampyridae in Hong Kong with descriptions of new species (Coleoptera): Part 2. Lampyrid 2017, 4, 67-119.

45. Jusoh, W.F.A.; Ballantyne, L.; Chan, K.O. DNA-based species delimitation reveals cryptic and incipient species in synchronous flashing fireflies (Coleoptera: Lampyridae) of Southeast Asia. Biol. J. Linn. Soc. 2020. [CrossRef]

46. Bourgeois, J. Dascillides \& Malacodermes de Nouvelle-Calédonie. Rev. d'entomologie 1884, 3, $278-290$.

47. Pic, M. Deuxième addenda. Faune Entomol. l'Indo-Chine Française 1923, 6, 58-63.

48. Pic, M. Malacodermes exotiques. L'Échange Rev. Linnéenne 1927, XLIII, 49. 
49. Olivier, E.H. Sauter's Formosa-Ausbeute: Lampyridae (Col.). Entomol. Mittellungen 1913, II, 271.

50. Bourgeois, J. Voyage du D.W. Horn à Ceylan. Malacodermes et Lymexylonides. II. Lampyridini. Ann. Société Entomol. Fr. 1905, 74,127

51. Olivier, E. Etudes sur les Lampyrides IV. Descriptions d'espèces nouvelles. Ann. Société Entomol. Fr. 1888, 6, 47-62.

52. Matsumura, M. The fireflies. In Using Interesting Insects as Teaching Tool; Tokyodô Shoten: Tokyo, Japan, 1928; pp. 39-70. (In Japanese)

53. Pic, M. Malacodermes exotiques. L'Échange, Rev. Linnéenne 1928, XLIV, 58-63.

54. Doi, H. A new species of Luciola from Korea. Luciola papariensis sp. nov. J. Chosen Nat. Hist. Soc. 1932, 14, 64.

55. Kiesenwetter, H. Die Malacodermen Japans nach den Ergebnisse der Sammlungen des Herrn L. Lewis während der Jahre 1869-1871. Dtsch. Entomol. Z. 1874, 18, 241-288.

56. Nakane, T. On the Cantharoid Coleoptera found in the islands of Tsushima (Insecta). Mem. Natl. Sci. Mus. 1970, 3, $287-288$.

57. Doi, H. A new species of Luciola from Korea. Luciola unmunsana sp. nov. J. Chosen Nat. Hist. Soc. 1931, 12, 54-55.

58. Tan, J.C.H. Fireflies of Pulau Ubin, Singapore. Nat. Singap. 2018, 11, 127-138.

59. Davison, G.W.H.; Ng, P.K.L.; Chew, H.H. The Singapore Red Data Book: Threatened Plants and Animals of Singapore, 2nd ed.; Nature Society (Singapore): Singapore, 2008; ISBN 9789810802004. 